\title{
EFFECT OF SOME FACTORS ON HONEY BEE VENOM PRODUCTION FROM DIFFERENT STRAINS
}

\section{Shimaa A. El-Bahnasy $^{1 *}$; H.M. Mahfouz ${ }^{1}$; A.A. El-Shibiny ${ }^{2}$ and M.N. El-Bassiony ${ }^{1}$}

1. Dept. Plant Prod., Fac. Environ. Agri. Sci., Arish Univ., Egypt.

2. Dept. Food Sci. and Micro., Fac. Environ. Agri. Sci., Arish Univ., Egypt.

\begin{abstract}
These experiments were carried out at the apiary of honeybee research center of Faculty of Environmental Agricultural Sciences, Arish University, North Sinai, Egypt. To study some factors that affecting on the honey bee venom collection (bee race, season of the year and supplemental protein nutrition) on collected venom quantity. The results showed that the Italian hybrid gave the largest quantity of venom. Spring and summer are the best seasons for collecting the largest quantity of the bee venom. The pollen grain and dried Moringa leaves diets treatments gave the best results for bee venom production comparing with the other treatments (mixture of soybean flour + pollen grains and sugar solution).
\end{abstract}

Key words: Honey bee, bee venom, bee race, protein nutrition.

\section{INTRODUCTION}

Bee venom is a clear liquid with bitter taste, aromatic odor and acidic reaction. It dissolves completely in water. Bee venom contains a number of pharmacologically active polypeptides. Chief among which are apamin, melittin and mast cell degranulating peptide that is known as peptide 401. This last component is both anti-inflammatory in rat models of chronic and acute inflammation (Shipolini, 1984).

Further important peptide in bee venom is apamine, a well characterized peptide (Dotimas and Hider, 1987). Apamine is a small peptide that corresponds to less $2 \%$ of venom dry weight. It has about $2.0 \mathrm{KDa}$, only 18 amino acid residues, and neurotoxic properties and does not exert any influence on a great variety of mammal cells (Hider, 1988). Bee venom is a colorless, sharp bitter tasting liquid with an aromatic odor that is similar to ripe bananas. It is slightly acidic ( $\mathrm{pH} 5.0$ to 5.5). Bee venom dries at an ambient temperature within about 20 minutes and loses $65 \%$ to $70 \%$ of its original weight. After the liquid has evaporated $0.1 \mathrm{mg}$ of pure whole dried venom can be collected per bee sting (Simics, 1994).

Omar, (2011) reported that venom production correlated negatively with the aggressiveness behavior of colony as the honey bee workers stingers were unstable on the collection boards over the colony frames produced $93.22 \% \mathrm{mg} /$ colony with significant increment $37.41 \%$ of dry bee venom compared with position at hive entrance.

Honeybee venom is a clear, odorless, watery liquid. When coming into contact with mucous membranes or eyes causes considerable burning and irritation. Dried venom takes on a light yellow color and some commercial preparations are brown, thought to be due to oxidation some of the venom proteins. Venom contains a number

\footnotetext{
* Corresponding author: Tel.: +201204789263
}

E-mail address: shimaa_bah@yahoo.com 
of very volatile compounds which are easily lost during collection (Krell, 1996). Natural food of honey bees is composed commonly of two components, pollens and bee honey or nectar. Pollens are the main source of proteins, amino acids, vitamins, fats and minerals; whereas honey and nectar represents the main sources of carbohydrates. Honey bees can be fed on various pollen substitutes to supplement inadequate supplies of pollen.

In early spring before pollen and nectar are available or at other times of the year when these materials are in short supply (dearth periods). Pollen substitutes help the colony to survive or to make it more populous and productive (El-Bandy and El-Sherif 1987). The aim of this study is to determine the effect of some factors that could increase the productivity of honeybee venom. This investigation discusses improving the production of the venom from honeybee's colonies by using the technique of electrical impulses.

\section{MATERIALS AND METHODS}

These experiments were carried out at the apiary of honeybee research center, Faculty of Environmental Agricultural Sciences, El-Arish University, North Sinai, Egypt.

Through three seasons: spring, summer and autumn during 2015 and 2016. To determine some factors affecting the bee venom collection like bee race, season of the year, and the kind of the nutrition on collected venom quantity.

\section{Bee venom collection}

New modern of the electric shock device was used in the present study. The device model used is VC-4FK from Apitronic Canada and depends on using electrical impulses to stimulate the bee workers to sting through latex sheet placed on glass plate which enables the bees to pull out their stings easily. In addition, the latex sheet prevents pollution of bee venom in order to obtain pure dry venom.

After drying on glass plate, the collected venom was scratched from the glass plate using sharp scraper and quickly packed in opaque glass vials, recorded its weight and Kept at $-4 \square \mathrm{C}$ till use.

\section{Some factors affecting the bee venom collection}

This work aimed to study the correlation between bee venom collected quantitative and bee hybrids, season of year of honey bee colonies. Also, the effect of supplemental protein nutrition on venom collection was studied.

\section{The honey bee hybrids}

The most two hybrids common in Egypt; Carniolian and Italian were subjected to study their efficiency to produce the bee venom and also the quality of this production.

\section{Seasons of the year}

The hybrids were tested throughout the year to know the best season to collect a large quantity of bee venom from the colonies. The tested seasons were: spring, summer and autumn.

\section{The supplemental protein nutrition}

This experiment was carried out to determine the effect of supplementary protein nutrition on the collection of bee venom. Twenty four honeybee colonies of Carniolan and Italian hybrids, relatively equal in their strengths were chosen. Twelve colonies concerted from each hybrid and divided into four groups (three colonies per each).

The supplemental protein diets were used as follow: 
Group (1): fed on $60 \mathrm{~g}$ of dried moringa leaves cake and bee honey $(1: 1 \mathrm{w}: \mathrm{w})$.

Group (2): fed on $60 \mathrm{~g}$ of cake of mixture of soybean flour, pollen grains and bee honey $(1: 1 \mathrm{~W}: \mathrm{W})$.

Group (3): fed on $60 \mathrm{~g}$ of cake of pollen grains only and bee honey (1:1w:w).

Group (4): without proteinaceous food (control).

All groups of the colonies were fed on $50 \%$ sugar solution in addition to the fore mentioned feeding regimes.

\section{Statistical analysis}

Data were subjected to statistical analysis by the SAS (2004) computer program using the general linear models (GLM). Significance among treatment means were tested using LSD Snedecor and Cochran (1972).

\section{RESULTS AND DISCUSSION}

\section{Bee hybrids}

The data obtained in Table 1 and Fig. 1 showed the quantity of bee venom which was collected every month (30 days) from the two honeybee hybrids during 2015 and 2016 season. No significant differences in the values of the bee venom weights with the two honeybee hybrids.

El-Shaarawy et al. (2007) recorded that Egyptian race and Carniolan hybrid produced highest venom quantities among other tested bee races during spring, summer and winter seasons by using an electrical shock device.

\section{Seasons of the year}

Relationship between different seasons of the year and type of honeybee hybrid on bee venom weights during 2015 and 2016 seasons

Results presented in Table 2 and Fig. 2 show the amount of bee venom that collected during the three seasons of the year (spring - summer - autumn) with the two hybrids (Carniolian hybrid - Italian hybrid). The Carniolian hybrid in the summer season gave the highest amount of bee venom $(0.079 \mathrm{mg} / \mathrm{col}$.) during 2015 season. While the Italian hybrid in the spring season gave the highest amount of bee venom $(0.084 \mathrm{mg} / \mathrm{col}$.) during 2016 season. The lowest amount of bee venom was recorded by the Carniolian hybrid during autumn season $(0.013$ and $0.015 \mathrm{mg} /$ col.) for the years of 2015 and 2016, respectively. These results are in agreement with those found by Nasser (2013) who showed that the highest amount of dry bee venom 15 min. was obtained in spring and summer seasons and the least amount was in winter seasons.

El-Shaarawy et al. (2007) collected honey bee venom during the four seasons of the year. The spring season recorded the highest weights in bee venom collection between the other seasons and the winter season was the lowest in bee venom quantity. So, from the previous results the best seasons, to collect the largest quantity of the bee venom, was the spring followed with the summer season.

\section{The supplemental protein nutrition}

The bee venom was collected every month from two honeybee hybrid (Carniolian hybrid - Italian hybrid) that fed on three different protein nutrition diets (air dried moringa leaves - pollen grains - soya bean flour+ pollen grains) for a month before collecting the venom and during the collection to determine the effect of the protein nutrition on bee venom weights.

Relationship between different nutrition diets and seasons (autumn, spring and summer) on bee venom weights collected from the two honeybee hybrids during 2015 and 2016 seasons

Results presented in Fig. 3 and 4 shows overlap between the three seasons of the year (spring - summer-autumn) and different 
Table (1): The bee venom weights collected from the two honeybee hybrids during 2015 and 2016 seasons.

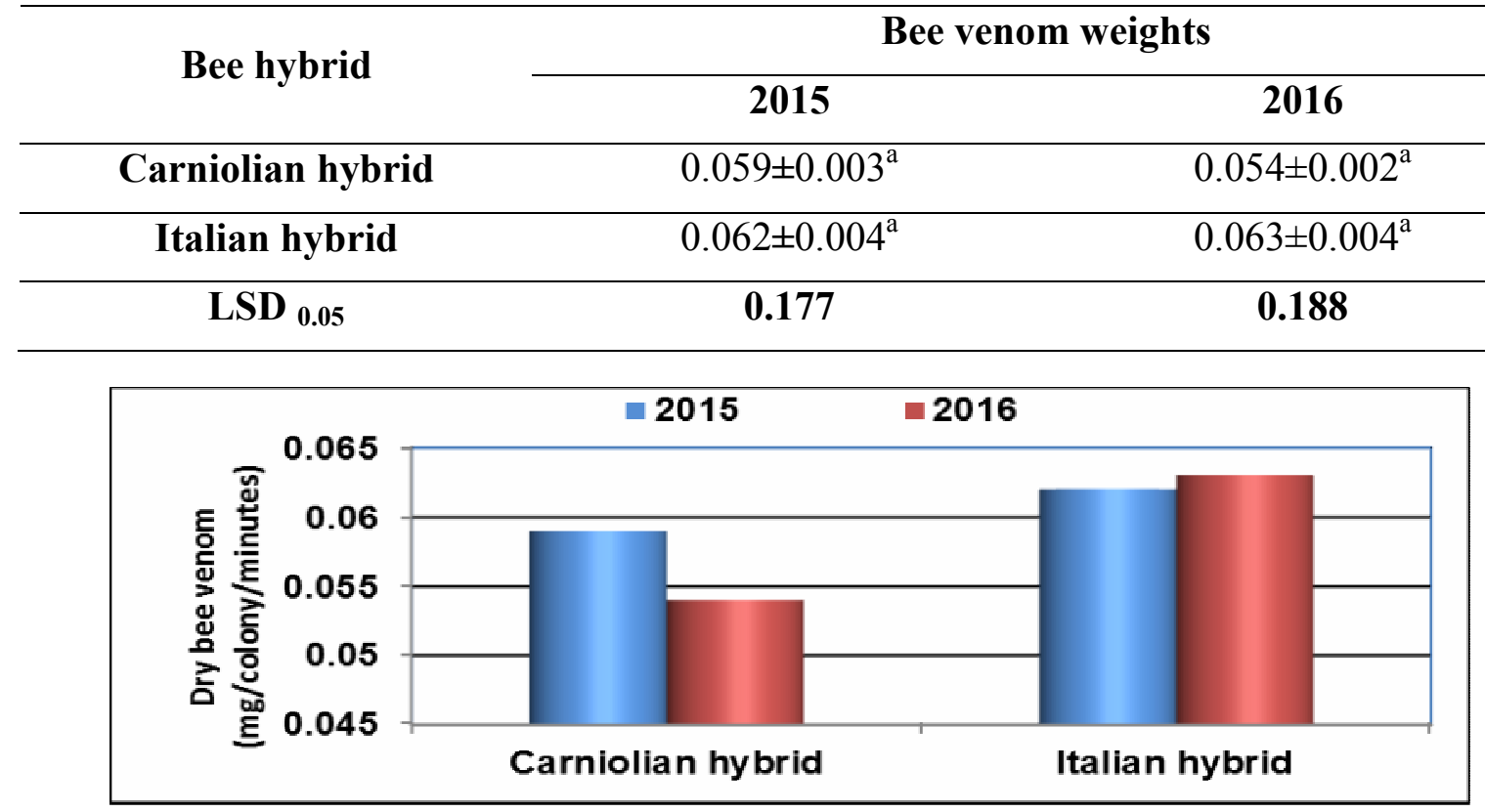

Fig. (1): The bee venom weights collected from the two honeybee hybrids during 2015 and 2016 seasons.

Table (2): Relationship between different seasons of the year and type of honeybee hybrid on bee venom weights during 2015 and 2016 seasons.

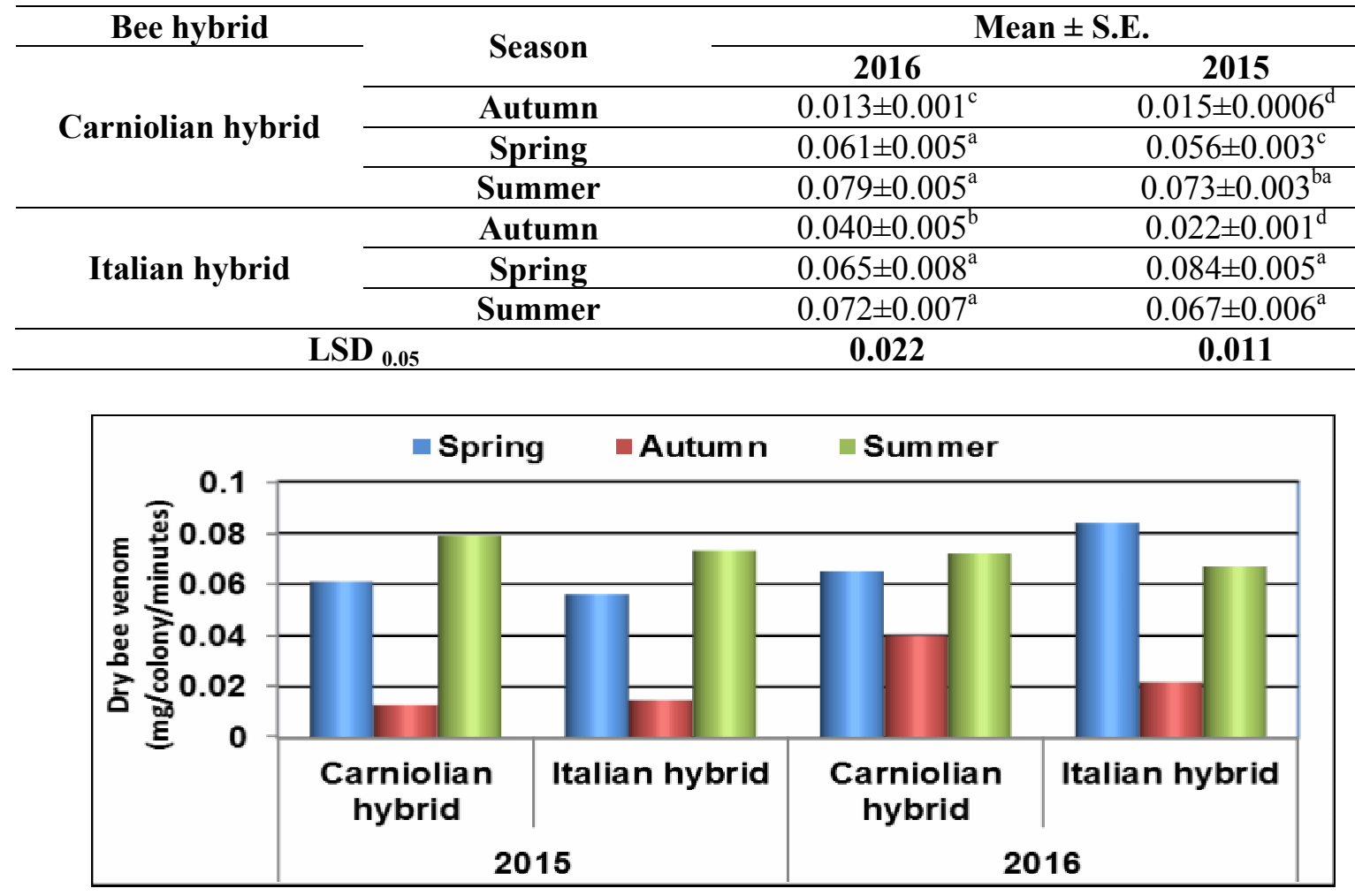

Fig. (2): Relationship between different seasons of the year and type of honeybee hybrid on bee venom weights during 2015 and 2016 seasons. 
SINAI Journal of Applied Sciences (ISSN: 2314-6079) Vol. (6) Is. (1), Apr. 2017

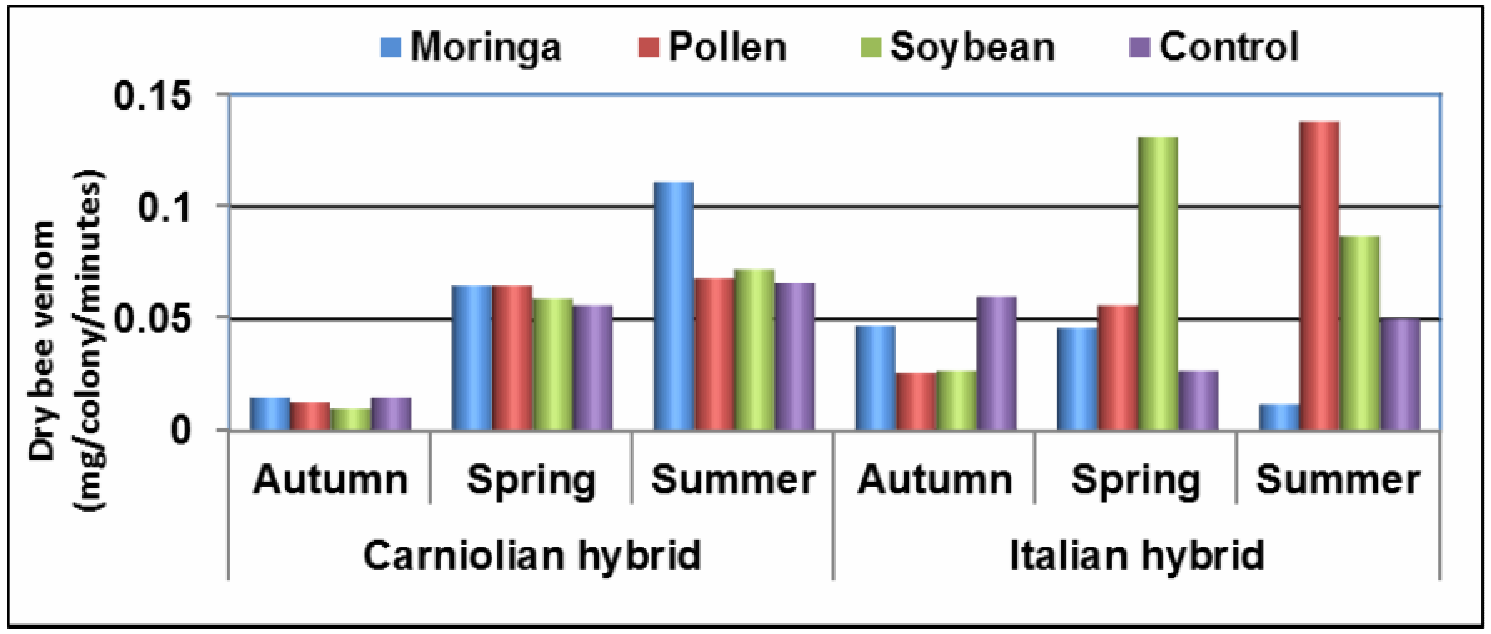

Fig. (3): Relationship between different nutrition diets and seasons (autumn, spring and summer) on bee venom weights collected from the two honeybee hybrids during 2015 season.

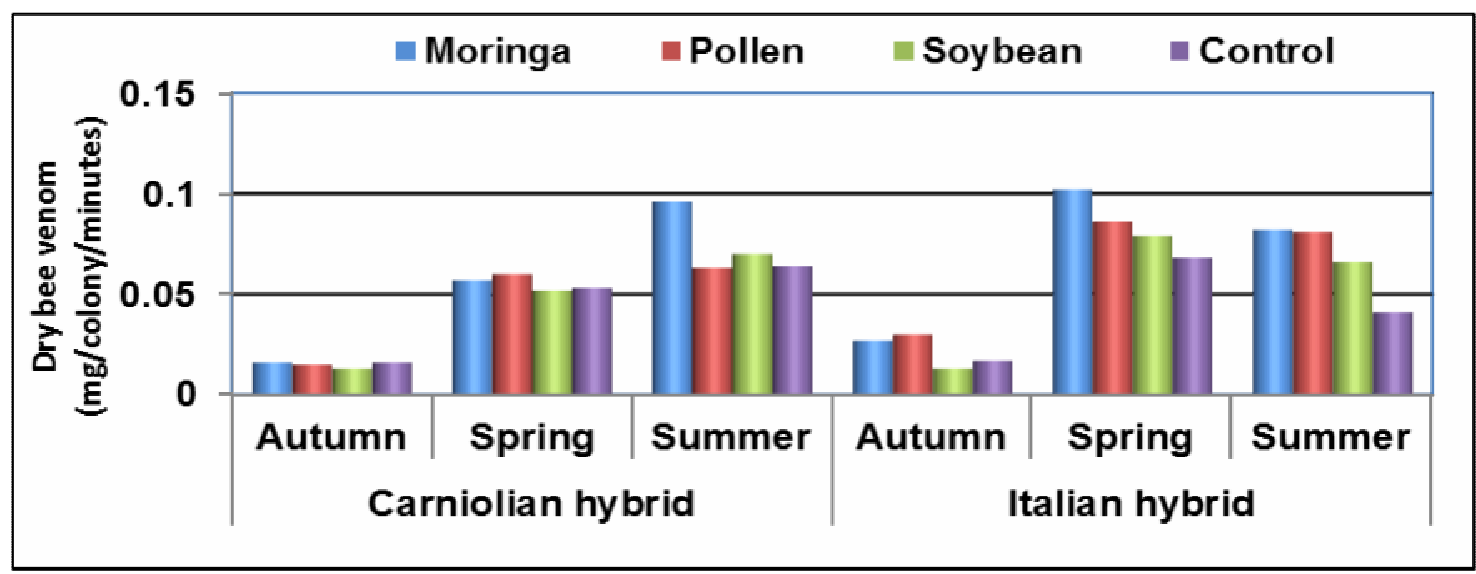

Fig. (4): Relationship between different nutrition diets and seasons (autumn, spring and summer) on bee venom weights collected from the two honeybee hybrids during 2016 seasons.

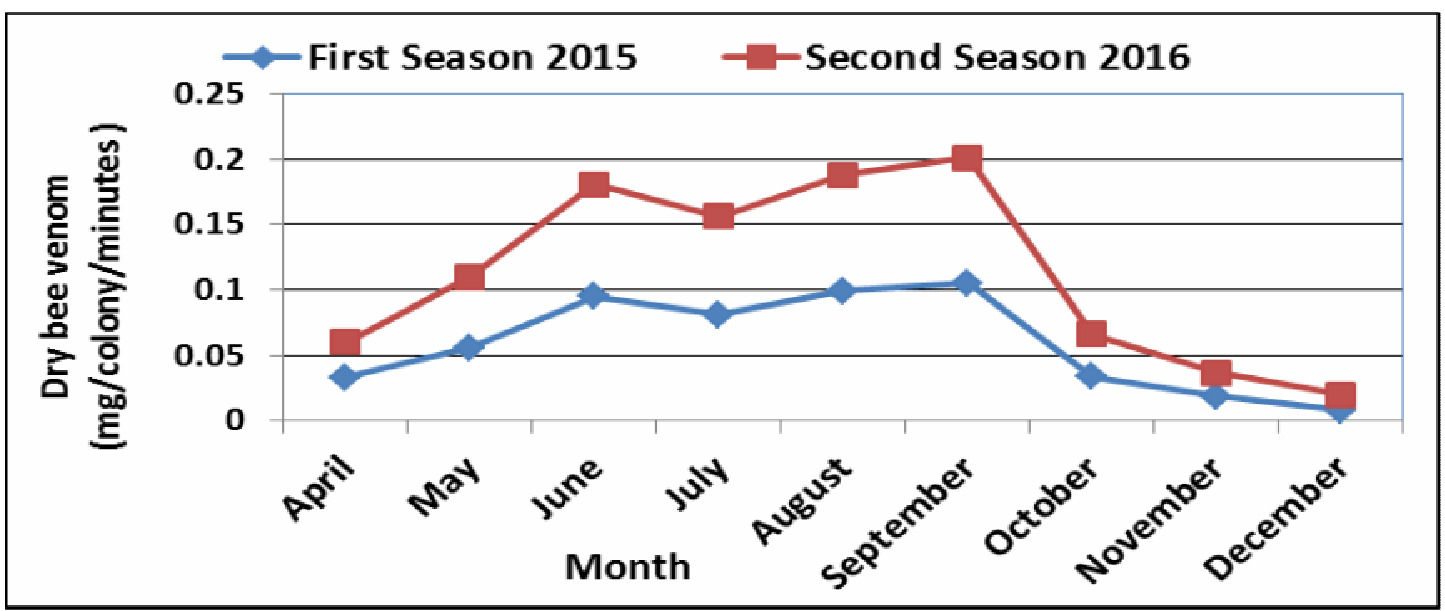

Fig. (5): Effect of different months of the year on the amount of bee venom weights (gm/ col.) collected from Carniolian hybrid during seasons of 2015 and 2016. 
types of nutrition with the two hybrids (Carniolian hybrid - Italian hybrid) on the amount of bee venom in honey bee colonies during 2015 and 2016 seasons. Results indicated that Italian hybrid in the summer season when feeding on pollen grains gave the highest amount of bee venom. The lowest amount of bee venom was recorded by the Carniolian and Italian hybrid in the autumn season when feeding on soybean in 2015 season. While Italian hybrid gave the highest amount of bee venom in the spring season when feeding on moringa in 2016 season.

Effect of different months of the year on the amount of bee venom weights ( $\mathrm{g} / \mathrm{col}$.) collected from Carniolian and Italian hybrid during seasons of 2015 and 2016

\section{Carniolian hybrid}

Results obtained in Fig. 5 show the quantity of bee venom extracted from Carniolian hybrid during months of the year of 2015 and 2016. September recorded the highest amount of bee venom $(0.105$ and $0.096 \mathrm{~g} / \mathrm{col}$.). While the lowest amount of bee venom $(0.008$ and $0.012 \mathrm{~g} / \mathrm{col}$.) were recorded in December in seasons of 2015 and 2016.

\section{Italian hybrid}

Results obtained in Fig. 6 show the quantity of bee venom extracted from Italian hybrid during months of the year of 2015 and 2016. August recorded the highest amount of bee venom $(0.14$ and 0.133 $\mathrm{g} / \mathrm{col}$.). While the lowest amount of bee venom $(0.012$ and $0.018 \mathrm{~g} / \mathrm{col}$.) were recorded in December in seasons of 2015 and 2016.

These results are in agreement with those found by Sanad and Mohanny (2013) who showed that the best period for collecting bee venom was between $4 \mathrm{pm}$ to $6 \mathrm{pm}$ at August month, as summer season giving the highest weights of bee venom (0.0185 g/day). Mohanny (2005) according to different months of the year, the collected quantities fluctuated from 0.8387 $\mathrm{g} /$ colony in August (the greatest) to 0.0386 $\mathrm{g} /$ colony in December (the lowest).

According to the different seasons, the collected quantities could be arranged descending as follows: summer, spring, autumn and winter. El-Ashhab (2001) found that the highest quantity was recorded in June $(0.33 \mathrm{mg} / \mathrm{col}$.) followed in October and December (0.313 and $0.243 \mathrm{~g}$ ). Nentchev (2001) found that the most bee venom was obtained in June and July, and the least in March and October.

In general, best quantities of bee venom were collected from the Italian hybrid where it gave the highest amount of bee venom during the three collection seasons. So, it could be suggested that the race of honeybee plays an important role in the amount of bee venom production by honeybee colonies.

The different between the two strains in their ability to produce venom is linked to many things like:

* The aggressive of bee strain that lead to clustering of bee workers and attacking with massive stinging workers.

* Number of bee worker in the colony in the age of defending the colony meaning more bee workers are capable to sting.

* The size of the bee worker that means with bigger size comes bigger venom sac and bigger venom apparatus so bigger venom quantity.

* The ability of bee worker to fill bakes the venom sac for what taken before the next collection time.

El- Ashhab (2001), El- Shaarawy et al. (2007) and Omar (2011) showed that the venom production correlated negatively with the aggressiveness behavior of colony as the honey bee workers stingers were unstable on the collection boards over the colony frames produced $93.22 \% \mathrm{mg} /$ colony with significant increment $37.41 \%$ of dry bee venom compared with position at hive entrance. 


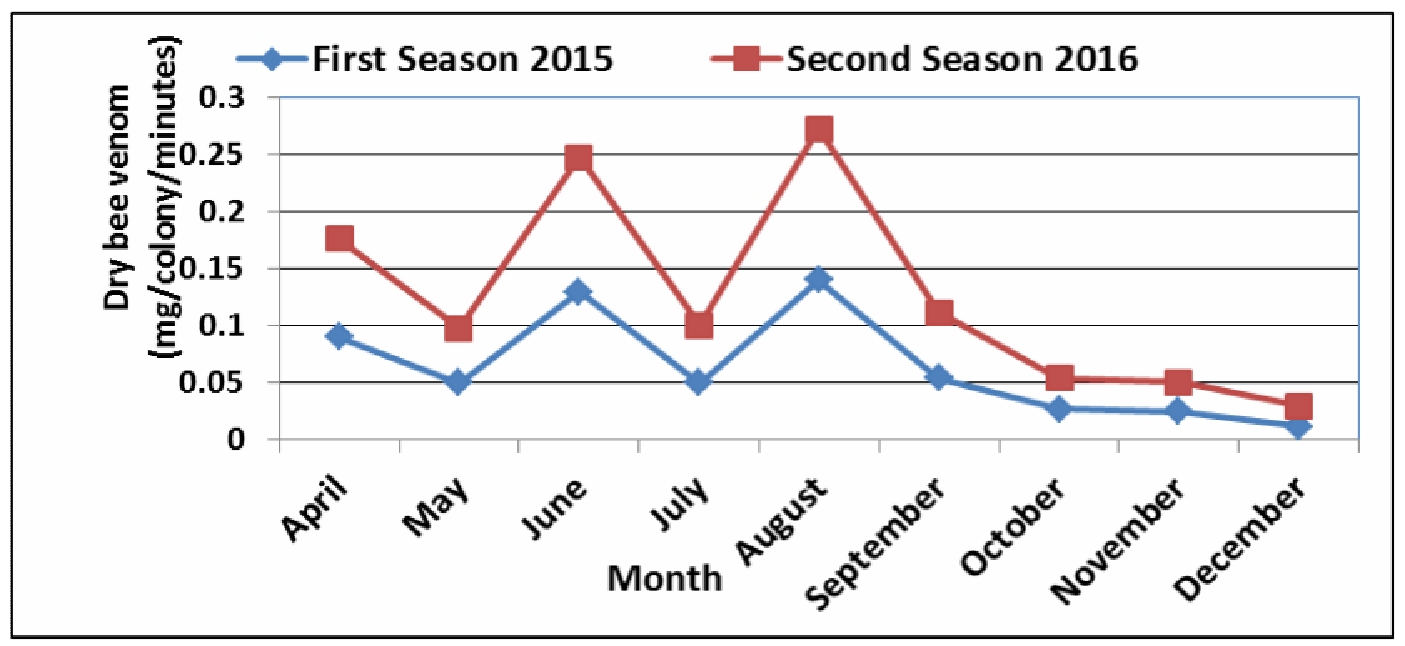

Fig. 6. Effect of different months of the year on the amount of bee venom weights $(\mathrm{gm} / \mathrm{col}$.) collected from Italian hybrid during seasons of 2015 and 2016.

Anwar Asmaa (2000) stated that the hive production of bee venom ranged between 33.5 - $37.0 \mathrm{mg}$ during summer season. The Italian bees have the heavies while, the Carniolan have the lowest amount of bee venom production. The mean weights were $37.0,34.0$ and $33.0 \mathrm{mg}$ during spring for Italian, Midnite and Carniolan, respectively. These means were $35.0,30.0 \mathrm{mg}$ during summer. Finally, using electrical impulses technique for venom collection will increase the income of beekeepers beside to other products and open the door to use the venom preparation for human health at large scale due to the multiplicity benefits and its uses.

\section{REFERENCES}

Anwar, A.E. (2000). Further Studies on Bee Venom Extraction and its Biological Properties. Ph.D. Thesis, Fac. Agric., Menoufiya Univ.

Dotimas, E.M. and Hider, R.C. (1987). Honey Bee Venom. Bee world, 68(2): 51-70.

El-Ashhab, K. (2001). Studies on Bee Venom in Honey Bee Colony., M.Sc. Thesis, Fac. Agric., Moshtohor, Zagazig Univ., 125.
El-Bandy, M.A. and El-Sherif, M.E. (1987). Comparison between Brewer's Yeast and Fortified Maize and Sorghum Flours as Pollen Substitutes. $2^{\text {nd }}$ Nat. Conf. Pests \& Dis. Veg. and Fruits Ismailia Oct. 1987.

El-Shaarawy，K.O.; Zakariam, M.E.; Azza Taufik, A. and El-Shemy, A.A.M. (2007). Effect of different bee venom collection periods using electrical shock device on some venom characteristics and honey bee colonies activities. J. Agri. Sc., Mansoura Univ., 32 (6): 4769-4775.

Hider, R.C. (1988). Honey bee venom: a rich source of pharmacologically active peptides. Endeavour, 12:60-65.

Krell, R. (1996). Value Added Products from Beekeeping. FAO Agricultural services Bulletin, No. 124. Ch. 7.

Mohanny, K.M. (2005). Investigation on Propolis and Bee Venom Produced by Two Hybrids of Honeybee with Reference to a New device for Bee Venom Collection., Ph.D. Thesis, Fac. Agric., El-Fayoum Univ.

Nasser, M.A. (2013). Studies on Some Factors Affecting Bee Venom Production. M.Sc. Thesis, Fac. Environ. Agri. Sc., El- Arish, Suez Canal Univ. 
Nentchev, P. (2001). Bee venom yield from bee families with two queens in one bee hive. Zhivotnov dni-Nauki, Mir press, 38 (2): 122-124.

Omar, E.M.O. (2011). Some Factors Affecting Acid Glands and Honey Bee Venom Productivity. M.Sc. Thesis, Assiut Univ. J. Agri. Sc., 89 pp.

Sanad, R.E. and Mohanny, K.M. (2013). The efficacy of a new modified apparatus for collecting bee venom in relation to some biological aspects of honey bee colonies. J. Ame. Sc.; 9(10): 177-182.
SAS (2004). SAS Procedures Guide for Personal Computers, Statistical Analysis System Inst., Inc., Cary, N.C.

Shipolini, R.A. (1984). Biochemistry of Bee Venom, Hand Book of Natural Toxins, Marcel Dekkerin, 2: 49-85.

Simics, M. (1994). Bee Venom: Exploring the Healing Power, Allergy, 30: 59-65.

Snedecor, G.W. and Cochran, W.G. (1972). Statistical Method $6^{\text {th }}$ the Iowa State Univ. Press, Ames., Iowa, USA, 59.

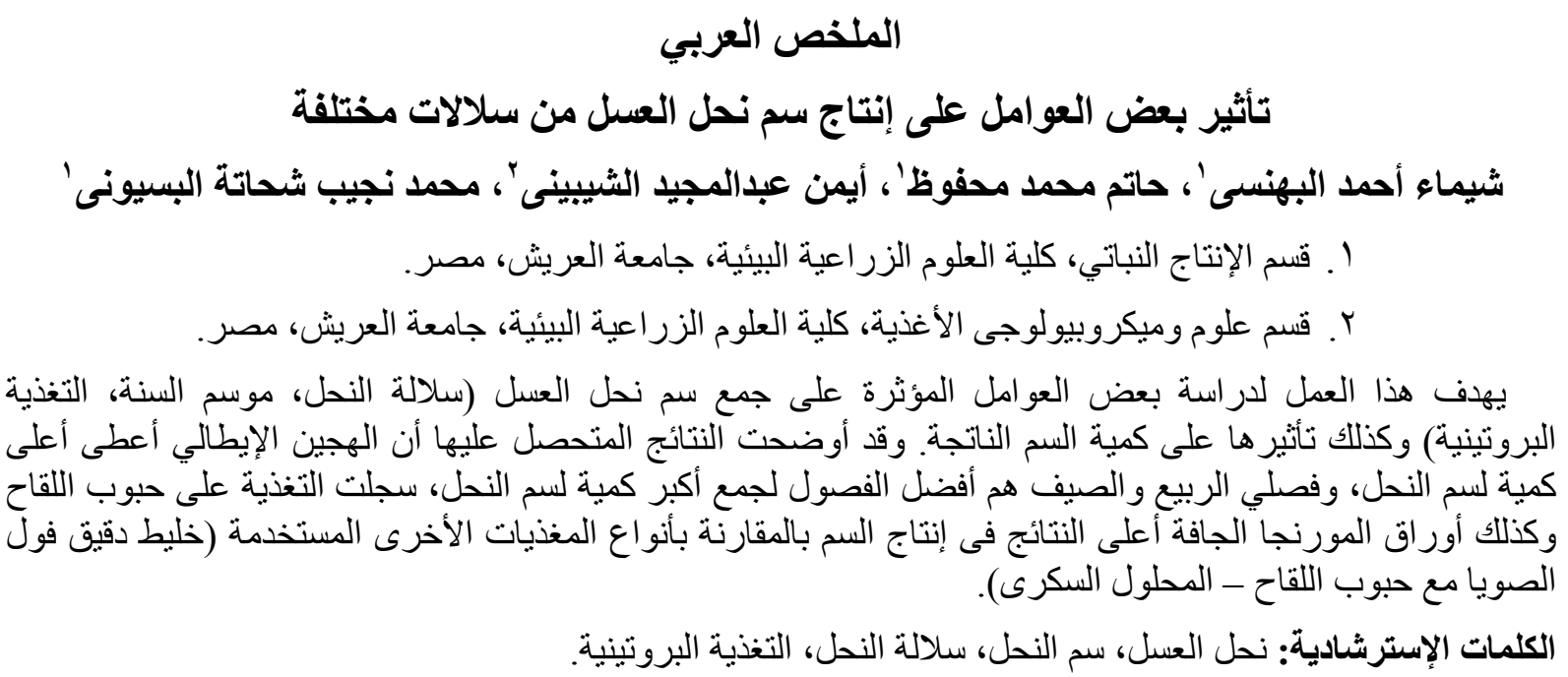

أستاذ الحشر ات الاقتصادية، كلية العلوم الزر اعية البيئية، جامعة العريش، مصر. 